\title{
Kitab Hadis Nusantara: Studi Atas Kitab Al-Arba'una Haditsan Karya Muhammad Yasin Al-Fadani, Padang
}

\author{
Ilyas Daud \\ IAIN Sultan Amai Gorontalo \\ yasirselebes@gmail.com
}

\begin{abstract}
This paper discusses about the characteristic of Hadith book written by on of scholars of archipelago named Sheikh Muhammad Yasin Al-Fadani which is the book of Arba'una Haditsan min Arba'ina Kitaban an Arba'ina Syaikhan. This study shows that the motivation of al-Fadani wrote this book iscause follows the predecessor scholars who compiled the book with forty hadith. This book have some characteristics;first, before presenting the honor tradition, its beginning with naming as the main reference book and author. Then the description of the genealogical chain of transmission that is long enough. The length of the description of this sanad is caused the explaining by al-Fadani is not departing from Imam mukharij as pentadwin hadith, but starting from Al-Fadani own. Secondly, when referring to the theory or concept of the preparation hadith method, the preparation book of Al-Arba'una Haditsan is follow Mustakhraj method. In terms of quality of knowledge, al-Fadani widely recognized for both of Arab scholars and the archipelago as scholar who mastered the science of hadith, especially sanad of hadith.
\end{abstract}

\begin{abstract}
Abstrak
Tulisan ini membahas tentang karakteristik kitab Hadis yang ditulis oleh salah satu ulama Nusantara bernama Syekh Muhammad Yasin Al-Fadani yaitu kitab Arba'una Haditsan min Arba'ina Kitaban an Arba'ina Syaikhan. Penelitian ini menunjukkan bahwa motivasi al-Fadani menulis kitab ini karena mengikuti ulama-ulama pendahulunya yang menyusun kitab dengan empat puluh hadis. Adapun karakeristik kitab ini pertama, sebelum menyajikan matan hadis, diawali dengan penyebutan nama kitab sebagai rujukan utama dan penulisnya. Setelah itu uraian silsilah sanad yang cukup panjang. Panjangnya uraian sanad ini sebab al-Fadani menjelaskannya tidak berangkat dari Imam mukharij sebagai pentadwin hadis, tapi dimulai dari Al-Fadani sendiri. Kedua, jika merujuk pada teori atau konsep metode penyusunan kitab hadis, kitab penyusunan kitab AlArba'una Haditsan ini mengikuti metode Mustakhraj. Dari segi kualitas pengetahuan, al-Fadani banyak mendapat pengakuan baik dari ulama Arab maupun Nusantara sebagai ulama yang menguasai ilmu hadis khususnya sanad hadis.
\end{abstract}

Keywords; karakteristik, Hadis, Nusantara, al-Fadani 


\section{A. Pendahuluan}

Kajian Hadis di Nusantara sudah dimulai pada abad ke17 Masehi, ditandai dengan munculnya kitab Hidayah al-Habib fi Targhib wa alTarhib yang ditulis oleh Nuruddin al-Raniri. ${ }^{1}$ Dilanjutkan dengan munculnya kitab Hadis 'Arba'in (empat puluh hadis karya al-Nawawi) dan kitab al-Mawa'id al-Badi'ah, sebuah koleksi hadis qudsi yang ditulis oleh Abd Rauf al-Sinkili. ${ }^{2}$ Perkembangan selanjutnya kajian hadis di Nusantara memasuki masa vakum, hal ini dilatarbelakangi oleh kondisi bangsa Indonesia yang dijajah oleh Belanda. Sikap agresif dan intimidatif Belanda sangat berdampak pada perkembangan ilmu pengetahuan. Barulah pada akhir abad ke19 atau memasuki abad ke-20 ditemukan kitab hadis yang disusun oleh ulama Indonesia, yaitu KH. Mahfudh Termas. ${ }^{3}$ dengan kitabnya yang berjudul; Manhaj Dhawi al-Nazaryang ia tulis ketika ia berada di Mekkah.Barulah mulai abad ke-20 kajian hadis di Indonesia mulai memperlihatkan kemajuan yang cukup signifikan.

Secara umum, kajian hadis di Nusantara seperti halnya kajian hadis kalangan mutaqaddiminterdiri dari dua fokus besar, yaitu: hadis dan ulumul hadis. Adapun bentuknya ada yang berupa terjemahan dari kitab berbahasa Arab dan ada juga yang merupakan karangan pemikiran sendiri seorang tokoh dengan menggunakan bahasa lokal maupun bahasa Arab, baik di tulis pada saat di Nusantara maupun pada saat berada di tanah Arab seperti yang dilakukan oleh Syekh Muhammad Yasin al-Fadani seorang ulama hadis Nusantara asal Padang yang sangat menguasai sanad hadis. Tulisan ini akan membahas salah satu kitab hadis beliau yaitu kitab alArba'ina Haditsan min Arba'ina Kitaban an Arba'ina Syaikhan.

Dari latar belakang tersebut, ada beberapa problem akademik sebagai pokok masalah yang hendak dijawab dalam penelitian ini adalah: apa motivasinya menyusun kitab Arba'una Haditsan? bagaimana karakteristik kitab al-Arba'una Haditsan min Arba'ina Kitaban an Arba'ina Syaikhan? Apa saja materi hadisnya dan sumber rujukannya? Bagaimana kualitas hadis-hadisnya? Dan bagaimana pula kualitas pengetahuannya dalam bidang hadis?

\footnotetext{
${ }^{1}$ Azyumardi Azra, Jaringan Ulama Timur Tengah dan Kepulauan Nusantara Abad XVII \& XVIII; Akar Pembaruan Islam di Indonesia (Jakarta: Kencana, 2013), h. 210.

${ }^{2}$ Ibid., h. 239.

${ }^{3}$ M. Bibit Suprapto, Ensiklopedi Ulama Nusantar, (Jakarta: Gelegar Media Indonesia, 2009), h. 464-466.
} 
Tujuan dari penelitian ini untuk memperoleh gambaran yang utuh tentang persepsi, motivasi, aspirasi al-Fadani menyusun kitab ini. Memperoleh gambaran pula tentang karakteristik kitab Arba'una Haditsan min Arba'ina Kitaban an Arba'ina Syaikhan baik dari aspek teknik, sistematika, maupun metode yang digunakan. Selain itu pula dapat mengetahui sisi kualitas pengetahuan al-Fadani dalam bidang hadis. Dengan mengetahui tujuan-tujuan tadi, dapat menjadi inspirasi dan motifasi bagi generasi sekarang untuk mencintai hadis seperti al-Fadani meskipun hidup di abad modern dengan segala tantangannya. Dengan metode deskriptif-analitis, tulisan ini dimaksudkan memberikan data yang seteliti mungkin tentang keadaan atau gejala dari objek yang diteliti, yaitu kitab Arb'una Haditsan min Arba'ina Kitaban an Arba'ina Syaikhan.

\section{B. Biografi Syekh al-Fadani}

Syekh Muhammad Yasin Bin Muhammad Isa Al-Fadani (lahir di Mekkah, Arab Saudi, 17 Juni 1915 meninggal di Mekkah, 20 Juli 1990 pada umur 75 tahun) adalah seorang ahli sanad hadis, ilmu falak, bahasa Arab, dan pendiri madrasah Darul Ulum al-Diniyyah, Mekkah. Beliau merupakan putra ulama terkenal, Syekh Muhammad Isa Al-Fadani asal Padang, Sumatera Barat. ${ }^{4}$

Sejak kecil Syaikh Yasin bin Isa Al-Fadani telah menimba ilmu agama dari ayahnya sendiri yang seorang ulama besar. Setelah itu beliau meneruskan thalabul ilmi nya kepada Syaikh Mahmud al-Fadani. Pada tahun 1346 hijriyah, beliau masuk di Madrasah Ash-shaulatiyah. Selama belajar di sana, beliau menunjukkan kecerdasan yang luar biasa dan sangat jarang ditemukan pada anak seusia beliau. Hal inilah yang membuat para guru beliau merasa takjub dan sangat mencintai beliau.

Namun pada sekitar tahun 1934 terjadilah konflik di shShauthiyyah. Penyebabnya adalah tindakan direktur ash-shaulatiyah yang tidak terpuji Dimana direktur ash-shaulatiyah telah menyinggung perasaan para pelajar asal Asia tenggara, terutama dari Indonesia. Sang Direktur menjadi tersangka perobekan surat kabar melayu yang dianggap sebagai bentuk pelecehan kepada martabat bangsa melayu. Karena itu kemudian beliau mengemukakan ide untuk mendirikan madrasah baru yang kemudian diberi nama madrasah Darul Ulum di Makkah. Setelah

\footnotetext{
${ }^{4}$ Lihat Jannatul Husna, Syeikh Yasin Padang dan Ilmu Tafsir: Sorotan Terhadap Fayd al-Khabir, Proceedings: The 2and Annual International Qur'anic Conference, Malaya University: 2012, 376
} 
madrasah baru ini selesai dibangun, para pelajar yang dari ash-Shaulatiyah banyak yang pindah ke Darul Ulum. Di Madrasah ini, Syaikh Yasin menjadi wakil direktur. Walau telah memiliki jabatan tinggi, namun beliau tetap melanjutkan thalabul ilmi-nya kepada para ulama-ulama besar kota Makkah dan tempat lainnya.

Beliau merupakan seorang pelajar yang haus akan ilmu. Bahkan ketika kelak menjadi ulama, beliau tetap haus ilmu. Beliau dikenal sebagai orang yang suka memburu sanad, silsilah periwayatan hadits dan ijazah ilmu atau kitab. Itulah sebabnya beliau mendapatkan gelar al-Musnid AdDunya atau pemilik sanad terbanyak di dunia. Hal ini karena beliau seorang ulama yang paling banyak memiliki sanad di dunia ini. ${ }^{5}$

\section{Karya-Karyanya}

Syaikh Yasin merupakan seorang ulama yang sangat produktif menulis kitab. Karyanya tidak kurang dari 100 kitab, dan kabarnya hingga hari ini para murid baru berhasil mengumpulkan kitab beliau sebanyak 97 kitab, dengan rincian 25 kitab tentang ilmu dan ushul fiqh, 36 kitab tentang ilmu falak, 9 kitab tentang ilmu hadits, dan sisanya tentang ilmu-ilmu lainnya. Selain itu, walaupun beliau berdarah melayu, namun keseluruhan kitab beliau ditulis dalam bahasa Arab. Berikut diantara kitab-kitab karya beliau yang masih dapat diketahui: ${ }^{6}$

1. Al-Arba'un Haditsan Mutsaltsal bi an-Nuhad ila al-Jalal asSuyuthi

2. Qurrat al- 'Ain fi Asanid A'lam al-Haramain

3. Al-Arba'un al-Buldaniyyah Arba'un Haditsan 'an Arba'in 'an Arba'in (terbit tahun $1407 \mathrm{H} / 1987 \mathrm{M}$ )

4. Al-Arba'un Haditsan min Arba'in Kitan 'an Arba'in 'an Arba'in Syaikhan (terbit tahun $1429 \mathrm{H} / 2008 \mathrm{M}$ )

5. Al-Muqtathaf min Ithaf al-Kabir bi Makkiy

6. Ailsilah al-Wushlah Majmu'ah Mukhatarah min al-Hadits alMustalsal

7. Fath ar-Rabb al-Majid fi Ma li Asyyakhi min Faraid al-Ijazah wa al-Asanid

8. Nihayat al-Mathlab fi 'Ulum al-Isnad wa al-Adab

${ }^{5}$ Ibid

${ }^{6}$ Ibid., h. 377 
9. Faidh ar-Rahmani bi Ijazat Samahah al-'Allamah al-Kabir Muhammad Taqi al- 'Utsmani (terbit tahun 1406 H/1986 M)

10. As-Salasil al-Mukhtarah bi Ijazah al-Muarrikh as-Sayyid Muhammad bin Muhammad Ziyarah

11. Ta'liqat 'ala Kifayat al-Mustafiq li asy-Syaikh Mahfudz atTurmusi

12. Al-'Ujalah al-Makkiyyah

13. Al-Waraqat 'ala al-Jawahir ats-Tsamin fi al-Arba' in Haditsan min al-Hadits Sayyid al-Mursalin ; dan

14. Ad-Durar an-Nadzir wa ar-Raudh an-Nadzir fi Majmu' al-Ijazah bi Tsabat al-Amir

15. Faidh ar-Rahman fi Tarjamah wa Asanid asy-Syaikh Khalifah bin Hamd an-Nabhan

16. Ittihaf ath-Thalib as-Sirri bi al-Asanid ila al-Wajih al-Kuzbari

17. Al-Asanid al-Faqih Ahmad bin Hajar al-Haitami al-Makki (terbit tahun $1429 \mathrm{H} / 2008 \mathrm{M}$ )

18. Tahqiq al-Jami' al-Hawi fi Marmiyat asy-Syarqawi

19. Ithaf al-Ikhwan bi Ikhtishar Majma' al-Wujdan (terbit tahun $1406 \mathrm{H} / 1986 \mathrm{M})$

20. dan masih banyak lagi lainnya

\section{Karakteristik Kitab al-Arba'una Haditsan}

\section{Penamaan Kitab}

Kitab ini secara lengkap bernama al-Arbauna Haditsan min Arba'ina Kitaban 'an Arbaina Syaikhan, ditulis oleh ulama besar bernama Muhammad Yasin al-Fadani (selanjutnya disebut al-Fadani) dan merupakan kitab hadis dari sekian banyak kitab hadis yang disusun oleh beliau. $^{7}$

Kitab ini berjumlah 88 halaman dengan memuat sebanyak 40 hadis Rasulullah SAW. Inilah alasan mengapa dinamakan dengan alArbauna Haditsan min arba' ina kitaban 'an arbaina syaikhan yang berarti empat puluh hadis dari empat puluh kitab karya empat puluh Syekh atau

\footnotetext{
${ }^{7}$ Buku al-‘Arbain yang pertama dan kedua diselesaikan pada tahun 1363. Jumlah hadis dalam setiap buku ada 40 hadis yang diriwayatkan oleh 40 Syeikh dan diambil dari 40 buku. Dan buku al-araba'in yang ketiga dan keempat diselesaikan pada tahun 1364. Jumlah hadis dalam setiap buku ada 40 hadis yang diriwayatkan oleh 40 syeikh dan diambil dari 40 kota. Lihat Abi Al-Faidh Muhammad bin Yasin Al-Fadani al-Maki, Arbauna Haditsan min Arbaina Kitaban an Arba'ina Syaikhan, (Beirut: Dar al-Basyair al-Islamiyah, $1407 \mathrm{H} / 1987 \mathrm{M})$, h. 4
} 
empat puluh imam hadis. Al-Fadani lebih suka membatasinya sampai empat puluh hadis disebabkan oleh beberapa alasan. Pertama, di awal pengantarnya beliau mengutip ayat QS. al-A'raf: $142 .{ }^{8}$

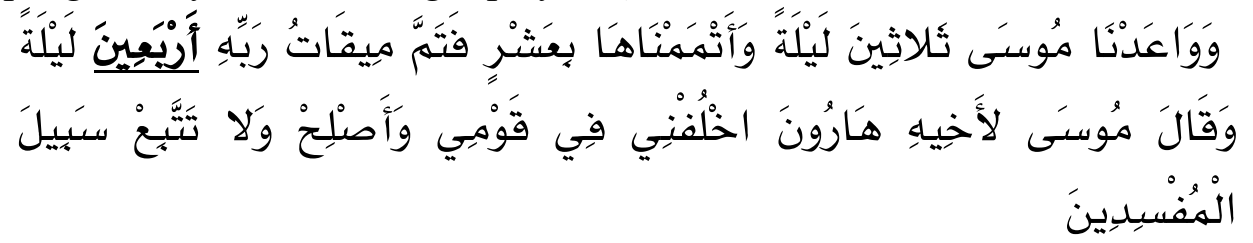

Dalam ayat di atas menjelaskan bahwa Nabi Musa mendapatkan taurat sebagai pemberian dari Allah setelah empat puluh malam. Inilah salah satu alasan al-Fadani menamakan kitabnya al-Arba'un.

Alasan kedua, beliau mengutip salah satu hadis Nabi: ${ }^{9}$

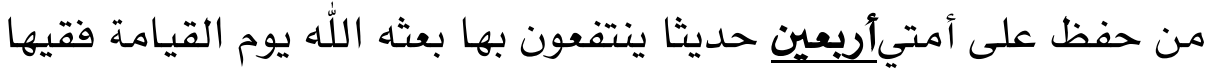

عالما

Hadis ini sering dikutip oleh para ulama ketika mereka memberikan pengantar dalam kitab yang memuat empat puluh hadis. Misalnya Imam an-Nawawi dalam pengantar kitabnya dalam kitab alArba'ina fi Mabani al-Islam wa Qawa'id al-Ahkam. Sepertinya hadis ini menjadi spirit bagi para ulama termasuk al-Fadani dalam mengumpulkan empat puluh hadis. ${ }^{10}$

Alasan ketiga, banyak para ulama terdahulu yang menyusun kitab dengan mengumpulkan sebanyak empat puluh hadis. Al-Fadani menyebutkan diantara para ulama tersebut adalah Imam Zahid Abdullah bin Mubarak dalam kitabnya al-Zuhd, Al-Hafidz Abu al-Qasim 'Ali bin Husain bin 'Asakir, dan pengumpulan hadis terbanyak dilakukan oleh Ismail bin Abdul Ghafir al-Farisi yang bisa mencapai 40-70an hadis. ${ }^{11}$

Keempat, al-Fadani disarankan oleh teman-teman mahasiswanya saat beliau diminta mengajarkan buku " al-Arba'ina fi mabani al-Islam wa Qawa'id al-Ahkam" karya Imam Nawawi di sekolah diniyyah Darul Ulum, Makkah, untuk mengumpulkan empat puluh hadis dalam satu kitab.

Setelah melakukan shalat istikharah, beliau pun mulai mengikuti jejak para ulama terdahulu dalam mengumpulkan hadis dan selalu

\footnotetext{
${ }^{8}$ Ibid., h. 3

${ }^{9}$ Ibid

${ }^{10}$ Abi Zakaria Muhyi al-Din bin Syarif al-Yadain al-Nawawi al-Syafi al-Damsyiqi, alArba'ina Fi Mabani al-Islami wa Qawa'id al-Ahkam, (ttp: tp, tth), h. 14

${ }^{11}$ Abi Al-Faidh Muhammad bin Yasin Al-Fadani al-Maki, Arbauna Haditsan, h. 3
} 
mengikuti cara yang mereka lakukan. Al-Fadani dalam mengikuti jejak pendahulunya tersebut termotivasi oleh sebuah riwayat yang mengatakan, "Barang siapa yang menyerupai suatu kaum, maka mereka termasuk dari kaum tersebut," dan ada juga bait puisi yang mengatakan, "Serupailah sebuah kaum meskipun engkau tidak bisa seperti mereka, karena sesungguhnya menyerupai sifat yang mulia adalah sebuah kemenangan". 12

\section{Teknik dan Sistematika Penulisan}

Meskipun al-Fadani berasal dari Indonesia, dan sangat menguasai bahasa Indonesia, namun kitab ini disusun dengan menggunakan bahasa Arab. Penggunaan bahasa Arab sebagai media penulisan kitab ini tentu bukan tanpa alasan. Ada beberapa alasan mengapa kitab ini ditulis dengan menggunakan bahasa Arab. Pertama, bahasa Arab adalah bahasa alQur'an dan hadis. Kedua, mengikuti ulama-ulama terdahulu yang menyusun kitab-kitab mereka berbahasa Arab, dan ketiga, lahirnya kitab ini di tanah Arab dan untuk menjawab persoalan-persoalan yang ada di tempat itu. Jadi kitab ini ingin menjawab konteksnya pada saat itu.

Sebelum menyajikan matan hadis, diawali dengan penyebutan nama kitab sebagai rujukan utama dan penulisnya. Setelah itu uraian silsilah sanad yang cukup panjang. Panjangnya uraian sanad ini sebab alFadani menjelaskannya tidak berangkat dari Imam mukharij sebagai pentadwin hadis, tapi dimulai dari Al-Fadani sendiri. Di sini beliau memosisikan diri sebagai mukharij (orang yang mengeluarkan hadis) terakhir. Penjelasan seperti ini berbeda dengan para ulama lainnya yang menjelaskan jalan sanad hanya sampai imam Mukharij hadis. Tentu perbedaan seperti ini disebabkan karena kepakaran beliau dalam sanad hadis.

Secara teknis, penulisan rantai sanad dari rawi pertama sampai dengan rawi terakhir tidak semuanya disatukan dalam satu paragraf. Rawi pertama sebagai periwayat langsung dari Nabi sampai dengan Imam Mukharij dipisahkan secara teknik penulisan dengan murid Imam hadis sampai pada periwayat terakhir yaitu gurunya al-Fadani. Pemisahan seperti ini tentu untuk memudahkan pembaca dalam memahami rantaian sanad yang begitu panjang tersebut.

Begitupula matan hadis disusun dalam satu paragraf sendiri, lalu paragraf berikutnya penjelasan kualitas hadis. Intinya dalam satu uraian

${ }^{12}$ Ibid 
hadis terdiri dari empat paragraf. Paragraf pertama rantai sanad dari gurunya al-Fadani sampai pada murid Imam Hadis, paragraf kedua menjelaskan sanad hadis dari Imam hadis sampai periwayat pertama yang menyaksikan langsung dari Nabi. Adapun paragraf ketiga adalah matan hadis dan paragraf terakhir menjelaskan kualitas hadis baik dari segi matan maupun sanad. Begitu seterusnya sampai penjelasan hadis yang keempat puluh.

Selain itu, kitab ini juga dilengkapi dengan sistem footnote atau catatan kaki. Catatan kaki ini merupakan syarah atau penjelasan dari uraian hadis di atas baik penjelasan terhadap sanadnya maupun matannya. Tetapi teknik penomoran dalam catatan kaki ini tidak berurutan sampai pada hadis terakhir. Pada setiap hadis, penomoran dalam catatan kaki tersebut dimulai dari awal. Jika dalam satu uraian hadis ada tiga syarah, maka penomoranya ditulis satu sampai tiga. Untuk syarah hadis berikutnya catatan kakinya dimulai lagi dari nomor satu.

Adapun sistematika penulisannya diawali dengan pengantar. Pegantar ini salah satunya menjelaskan tentang asal usul penyebutan nama kitab ini. Setelah itu menjelaskan sebanyak empat puluh hadis dari empat puluh kitab karya empat puluh Syekh atau Imam hadis. Kitab hadis pertama sebagai rujukan adalah kitab Shahih Bukhari oleh Imam Bukhari. Disusul kitab kedua adalah kitab Shahih Muslim, ketiga Sunan Abu Daud, keempat Jami al-Turmudzi, kelima Sunan an-Nasai, keenam Sunan Ibnu Majah, ketujuh Muwathai Imam Malik Riwayat Yahya bin Yahya alLaitsi, kedelapan Muwatha riwayat Muhammad bin Hasan, kesembilan alAtsar Muhammad bin Hasan, kesepuluh Sunan as-Syafi, kesebelas Sunan as-Syafi riwayat al-Rabi, keduabelas Musnad Ahmad bin Hanbal, ketigabelas al-Mustadrak al-Hakim, keempatbelas Sunan ad-Darimi, kelimabelas Sunan al-Daruquthni, keenambelas Mu'jam al-Shagir alTabrani, ketujuh belas, Mu'jam al-Wasith al-Thabrani, kedelapan belas Sunan al-Kubra al-Baihaqi, kesembilan belas Asma wa shifat al-Baihaqi, kedua puluh al-Adab al-Mufrad al-Bukhari, kedua puluh satu Shahih Abi Awanah, kedua puluh dua al-Muntaqi Ibn al-Jaruwadi, kedua puluh tiga Musnad al-Tayalusi, kedua puluh empat Sunan Abi Muslim al-Kaji, keduapuluh lima Musnad Abi Na'im Ibn Adi al-Jurjani, dua puluh enam Musnad Abd bin Hamid, dua pulub tujuh Musnad al-Kubra al-Bujari, dua puluh delapan Musnad al-Hamidi, dua puluh sembilan Musnad Ishaq, tiga puluh Mushannaf Abd. Razaq, tiga puluh satu Musnad Abi Ya'la, tiga puluh dua Musnad Abi Bakar bin Abi Syaibah, tiga puluh tiga Musnad Abi Zakaria al-Himmani, tiga puluh empat Musnad Al-Bughawi, tiga puluh 
lima Musnad Hannad, tiga puluh enam Musnad Muthayyin, tiga puluh tujuh Musykil al-Atsar, tiga puluh delapan Sunnah Al-Kai, tiga puluh sembilan Hulyatul Awliya, empat puluh Amalul al-Yaumiah al-Lailah Ibn Sin. Pada bagian terakhir dari kitab ini memuat daftar isi yang terdiri dari nama kitab dan perawi terakhir sebagai gurunya al-Fadani.

\section{Metode Penyusunan}

Dalam ilmu hadis selama ini dikenal ada kurang lebih sembilan metode penyusunan kitab hadis, yaitu Mushannaf, Musnad, Sunan, Jam'i, Ajza', Shahih, Athraf, Mustakhraj, Al Mustadrak.

Pertama Mushannaf. Menurut istilah ahli hadis Mushannaf adalah sebuah kitab hadis yang disusun berdasarkan bab-bab fiqhi, yang didalamnya terdapat hadis marfu', mauquf, dan maqtu'. Karena mushannaf adalah kitab hadis yang disusun berdasarkan kitab fiqih, maka Muwatta' termasuk didalamnya. ${ }^{13}$

Kedua Musnad. Sebuah kitab hadis dinamakan Musnad apabila ia memasukkan semua hadis yang pernah ia terima dengan tanpa menerangkan derajat ataupun nyaring hadis-hadis tersebut. Kitab musnad berisi tentang hadis-hadis kumpulan hadis, baik itu hadis shahih, hasan dhaif. Atau kitab hadis yang disusun menurut nama rawi pertama yang menerima dari Rasul selanjutnya sampai pada perawi terakhir. ${ }^{14}$

Ketiga Sunan yaitu kitab-kitab yang disusun berdasarkan bab-bab tentang fiqhi dan hanya memuat hadis-hadis yang marfu' saja agar dijadikan sumber bagi para Fuqaha dalam mengambil sebuah kesimpulan. As-Sunan tidak terdapat pembahasan tentang Sirah, Aqidah, Manaqib, dan lain-lain. As-sunan hanya membahas masalah fiqhi dan hadis-hadis hukum saja. Al-Kittana mengatakan bahwa susunan kitab sunan berdasarkan bab-bab tentang fiqhi mulai bab tentang Iman, Tharah, Sholat, Zakat, Puasa, Haji, dan seterusnya. ${ }^{15}$

Keempat Jam'i berarti sesuatu yang mengumpulkan, mencakup dan menggabungkan. Kitab Jam'i adalah kitab hadis yang metode penyusunannya mencakup seluruh topik-topik agama, baik Aqidah,

\footnotetext{
${ }^{13}$ M. Hasbi Ash shiddiqiy, Sejarah Pengantar Ilmu Hadis, (Cet.VIII; Semarang:pustakarizki putra, 2001), h.194

${ }^{14}$ Ibid., hlm. 177

${ }^{15} \mathrm{Ibid}$
} 
Thaharah, Ibadah, Mu'amalah, pernikahan, Sirah, Riwayat Hidup, Tafsir, Tazkiyatun Nafs, dan Lain-lain. ${ }^{16}$

Kelima Ajza'. Metode ini menurut istilah muhadditsin adalah kitab yang disusun untuk menghimpun hadis-hadis yang diriwayatkan oleh satu orang, baik dari generasi sahabat maupun dari generasi sesudahnya. Seperti Juz Hadis Abu Bakar dan Juz Hadis Malik. Pengertian yang lain adalah kitab hadis yang memuat hadis-hadis tentang tema-tema tertentu, seperti Al-juz'u fi Qiyamil lailiy, karya Al-Marwazi dan Fawaidul Hadisiyah, juga kitab Al-wildan karya Imam Muslim dan Yang lainnya. ${ }^{17}$

Keenam Shahih. Kitab hadis dinamakan Shahih apabila dalam penulisannya penulis hanya mencantumkan hadis-hadis yang dianggap shahih saja oleh penulis. Contoh kitab shahih adalah Sahih Bukhari dan kitab Shahih Muslim.

Ketujuh al-Athraf. Metode ini maksudnya adalah kumpulan hadis dari beberapa kitab induknya dengan cara mencantumkan bagian atau potongan hadis yang diriwayatkan oleh setiap sahabat. Penyusunan hanyalah menyebutkan beberapa kata atau pengertian yang menurutnya dapat dipahami hadis yang dimaksud. Sedangkan sanad-sanadnya terkadang ada yang menulisnya dengan lengkap dan ada yang menulisnya dengan mencantumkan sebagiannya saja. ${ }^{18}$

Kedelapan Mustakhraj adalah kitab hadis yang memuat matanmatan hadis yang diriwayatkan oleh Bukhary atau Muslim atau keduaduanya atau lainnya, kemudian sipenyusun meriwayatkan matan-matan hadis tersebut dengan sanad sendiri yang berbeda. Misalnya: mustakhraj shahih bukhary susunan Al-Jurjani. ${ }^{19}$

Kesembilan al-Mustadrak. Penyusun kitab al-Mustadrak adalah kitab yang disusun untuk memuat hadis-hadis yang tidak dimuat didalam kitab-kitab hadis sebelumnya, padahal hadis itu shahih menurut syarat yang dipergunakan oleh ulama tersebut. Salah satu kitab Mustadrak yang terkenal adalah al Mustadrak ala Shahihaini karya al Hakim al Naisaburi $(321-405 \mathrm{H}){ }^{20}$

\footnotetext{
${ }^{16}$ Ibid., hlm.83

${ }^{17}$ M. Hasbi As Shiddiqiiy, pokok-pokok ilmu dirayah hadis, (Jilid II;Cet,VIII; Jakarta :Bulan Bintang,tth), h.325

${ }^{18} \mathrm{Abu}$ Muhammad Abduh Mahdi, Metode Tahkrijul Hadis, terj. Said Agil Husin Munawar dkk. (Cet. I, Semarang: Dina Utama Semarang, 1994), h.79

${ }^{19}$ M. Shudi Ismail, Cara Prakti Mencari Hadis, (Cet,I;Yogyakarta :Teras,2003),h.121

${ }^{20}$ Abu Abdillah al Hakim Al Naisaburiy, Al Mustadrak Al Shahihaini, (Juz I, Beirut : Dar Al Fikr, 1918), h.3
} 
Jika merujuk pada teori atau konsep metode penyusunan kitab hadis di atas, kitab penyusunan kitab Al-Arba'una Haditsan ini sesuai penyelidikan penulis mengikuti metode Mustakhraj. Metode ini sebagaimana dijelaskan di atas adalah metode kitab hadis yang memuat matan-matan hadis yang diriwayatkan oleh Bukhari atau Muslim atau kedua-duanya atau lainnya, kemudian si penyusun meriwayatkan matanmatan hadis tersebut dengan sanad sendiri yang berbeda.

\section{Sumber dan Materi Hadis}

Sebagaimana dijelaskan di atas bahwa al-Fadani tidak tematik saat menyusun kitab ini. Beliau mengumpulkan sebanyak empat puluh hadis yang berkaitan dengan banyak hal. Untuk lebih jelasnya Sumber hadis, isi hadis beserta dengan kualitasnya dapat dilihat pada tabel di bawah ini:

\begin{tabular}{|c|c|c|c|c|}
\hline No & $\begin{array}{l}\text { Sumber } \\
\text { Hadis }\end{array}$ & $\begin{array}{c}\text { Penyusun } \\
\text { Kitab }\end{array}$ & Isi/ Materi Hadis & Kualitas \\
\hline 1 & $\begin{array}{l}\text { Shahih } \\
\text { Bukhari }\end{array}$ & $\begin{array}{l}\text { Muhammad } \\
\text { bin Ismail al- } \\
\text { Bukhari }\end{array}$ & $\begin{array}{l}\text { keutamaan Bukit 'Aqiq } \\
\text { (bukit yang diberkahi) } \\
\text { seperti keutamaan kota } \\
\text { Madinah, dan keutamaan } \\
\text { Shalat di tempat itu }\end{array}$ & Shahih \\
\hline 2 & $\begin{array}{l}\text { Shahih } \\
\text { Muslim }\end{array}$ & $\begin{array}{l}\text { Abu al-Walid } \\
\text { Muslim bin } \\
\text { Hujaj al- } \\
\text { Qusyairi al- } \\
\text { Naisaburi }\end{array}$ & $\begin{array}{l}\text { Keutamaan Persaudaraan } \\
\text { Sesama muslim, tidak } \\
\text { saling menganiaya, saling } \\
\text { menjaga, memenuhi } \\
\text { kebutuhannya dan } \\
\text { menutupi aibnya } \\
\end{array}$ & Shahih \\
\hline 3 & $\begin{array}{l}\text { Sunan Abu } \\
\text { Daud }\end{array}$ & $\begin{array}{l}\text { Abu Daud } \\
\text { Sulaiman bin } \\
\text { Asy'ats al- } \\
\text { Sijistani al- } \\
\text { Azdi }\end{array}$ & Anjuran Shalat Tasbih & Hasan Gharib \\
\hline 4 & $\begin{array}{l}\text { Jami al- } \\
\text { Tirmidzi }\end{array}$ & $\begin{array}{l}\text { Abu Isa al- } \\
\text { Hafiz } \\
\text { Muhammad } \\
\text { bin Isa bin } \\
\text { Saurah al- } \\
\text { Tirmidzi } \\
\end{array}$ & $\begin{array}{l}\text { Memohon pertolongan } \\
\text { kepada Allah, meminta } \\
\text { sesuatu kepada Allah. } \\
\text { Ketetapan Allah tidak bisa } \\
\text { di ubah oleh mahluk } \\
\text { siapapun }\end{array}$ & Shahih \\
\hline 5 & $\begin{array}{l}\text { Sunan an- } \\
\text { Nasai }\end{array}$ & $\begin{array}{l}\text { Abdul Karim } \\
\text { bin al-Hafiz } \\
\text { Ahmad bin } \\
\text { Syuaib an- } \\
\text { Nasai }\end{array}$ & $\begin{array}{l}\text { Ganjaran pahala Orang } \\
\text { yang berijtihad atau } \\
\text { menetepkan hukum }\end{array}$ & Shahih \\
\hline
\end{tabular}




\begin{tabular}{|c|c|c|c|c|}
\hline 6 & $\begin{array}{l}\text { Sunan Ibnu } \\
\text { Majah }\end{array}$ & $\begin{array}{l}\text { Abu Abdullah } \\
\text { Muhammad } \\
\text { bin Yazid ibn } \\
\text { Majah al- } \\
\text { Qazwini }\end{array}$ & $\begin{array}{l}\text { Orang bijak adalah orang } \\
\text { yang bisa menahan hawa } \\
\text { nafsunya }\end{array}$ & - \\
\hline 7 & $\begin{array}{l}\text { Muwathai } \\
\text { Imam } \\
\text { Malik } \\
\text { Riwayat } \\
\text { Yahya bin } \\
\text { Yahya al- } \\
\text { Laitsi }\end{array}$ & $\begin{array}{l}\text { Anas Bin } \\
\text { Malik }\end{array}$ & $\begin{array}{l}\text { Sahabat minta diajarkan } \\
\text { Nabi lafaz bershalawat } \\
\text { kepada Beliau }\end{array}$ & Shahih \\
\hline 8 & $\begin{array}{l}\text { Muwatha } \\
\text { riwayat } \\
\text { Muhamma } \\
\text { d bin } \\
\text { Hasan }\end{array}$ & $\begin{array}{l}\text { Anas Bin } \\
\text { Malik }\end{array}$ & $\begin{array}{l}\text { Sahabat minta diajarkan } \\
\text { Nabi lafaz bershalawat } \\
\text { kepada Beliau }\end{array}$ & Sanad Aziz \\
\hline 9 & $\begin{array}{l}\text { al-Atsar } \\
\text { Muhamma } \\
\text { d bin } \\
\text { Hasan }\end{array}$ & $\begin{array}{l}\text { Muhammad } \\
\text { Bin Hasan al- } \\
\text { Syaibani }\end{array}$ & $\begin{array}{l}\text { Surga bagi orang yang } \\
\text { mati dalam mengucapkan } \\
\text { dua kalimat syahadat }\end{array}$ & Shahih \\
\hline 10 & $\begin{array}{l}\text { Sunan as- } \\
\text { Syafi }\end{array}$ & $\begin{array}{l}\text { Muhammad } \\
\text { bin Idris as- } \\
\text { Syafi' }\end{array}$ & $\begin{array}{l}\text { Mendahulukan makan } \\
\text { malam dari pada Shalat }\end{array}$ & Shahih \\
\hline 11 & $\begin{array}{l}\text { Sunan as- } \\
\text { Syafi } \\
\text { riwayat al- } \\
\text { Rabi }\end{array}$ & $\begin{array}{l}\text { Muhammad } \\
\text { bin Idris as- } \\
\text { Syafi }\end{array}$ & $\begin{array}{l}\text { Membersikan wadah } \\
\text { sebanyak } 7 \text { kali bila dijilati } \\
\text { anjing, dan basuhan ke } 7 \\
\text { menggunakan tanah }\end{array}$ & Shahih \\
\hline 12 & $\begin{array}{l}\text { Musnad } \\
\text { Ahmad bin } \\
\text { Hanbal }\end{array}$ & $\begin{array}{l}\text { Abi al-Imam } \\
\text { Ahmad bin } \\
\text { Muhammad } \\
\text { bin Hanbal }\end{array}$ & $\begin{array}{l}\text { Larangan memanjangkan } \\
\text { kumis dan kuku }\end{array}$ & Hasan \\
\hline 13 & $\begin{array}{l}\text { al- } \\
\text { Mustadrak } \\
\text { al-Hakim }\end{array}$ & $\begin{array}{l}\text { Abu Abdullah } \\
\text { al-Hakim an- } \\
\text { Naisaburi }\end{array}$ & $\begin{array}{l}\text { Asmaul Husna/ Nama- } \\
\text { nama yang baik }\end{array}$ & Shahih \\
\hline 14 & $\begin{array}{l}\text { Sunan ad- } \\
\text { Darimi }\end{array}$ & $\begin{array}{l}\text { Abdullah bin } \\
\text { Abd. Rahman } \\
\text { bin al-Fadhl } \\
\text { al-Darimi }\end{array}$ & $\begin{array}{l}\text { Anjuran makan dengan } \\
\text { tangan kanan }\end{array}$ & - \\
\hline 15 & $\begin{array}{l}\text { Sunan al- } \\
\text { Daruquthni }\end{array}$ & $\begin{array}{l}\text { Muhammad } \\
\text { bin Ali ad- } \\
\text { Daruquthni }\end{array}$ & $\begin{array}{l}\text { Keutamaan mengucapkan } \\
\text { kalimat tauhid laa ilaha } \\
\text { illa Allah }\end{array}$ & Mukhtalif \\
\hline 16 & $\begin{array}{l}\text { Mu'jam al- } \\
\text { Shagir al- } \\
\text { Tabrani }\end{array}$ & $\begin{array}{l}\text { Abu al-Qasim } \\
\text { al-Thabrani }\end{array}$ & $\begin{array}{l}\text { Menolong saudara yang } \\
\text { dizhalimi dan menzhalimi }\end{array}$ & Shahih \\
\hline
\end{tabular}




\begin{tabular}{|c|c|c|c|c|}
\hline 17 & $\begin{array}{l}\text { Mu'jam al- } \\
\text { Wasith al- } \\
\text { Thabrani }\end{array}$ & $\begin{array}{l}\text { Abu al-Qasim } \\
\text { al-Thabrani }\end{array}$ & Keutamaan Silaturrahim & Gharib \\
\hline 18 & $\begin{array}{l}\text { Sunan al- } \\
\text { Kubra al- } \\
\text { Baihaqi } \\
\end{array}$ & $\begin{array}{l}\text { Ibn Musa al- } \\
\text { Baihaqi }\end{array}$ & Keutamaan Shalat & Hasan \\
\hline 19 & $\begin{array}{l}\text { Asma wa } \\
\text { shifat al- } \\
\text { Baihaqi }\end{array}$ & $\begin{array}{l}\text { Ibn Musa al- } \\
\text { Baihaqi }\end{array}$ & $\begin{array}{l}\text { Allah tidak melihat bentuk } \\
\text { fisik dan manusia, tetapi } \\
\text { melihat hati dan } \\
\text { amalannya }\end{array}$ & Shahih \\
\hline 20 & $\begin{array}{l}\text { al-Adab al- } \\
\text { Mufrad al- } \\
\text { Bukhari }\end{array}$ & $\begin{array}{l}\text { Abu Abdullah } \\
\text { al-Bukhari }\end{array}$ & $\begin{array}{l}\text { Berlepas diri dari hal-hal } \\
\text { yang merusak }\end{array}$ & - \\
\hline 21 & $\begin{array}{l}\text { Shahih Abi } \\
\text { Awanah }\end{array}$ & $\begin{array}{l}\text { Al-Hafiz Abu } \\
\text { Awanah }\end{array}$ & Jual Beli & - \\
\hline 22 & $\begin{array}{l}\text { al-Muntaqi } \\
\text { Ibn al- } \\
\text { Jaruwadi }\end{array}$ & $\begin{array}{l}\text { Abu } \\
\text { Muhammad } \\
\text { al-Hafiz } \\
\text { Abdullah } \\
\text { Abdullah bin } \\
\text { Ali bin } \\
\text { Jarwadi an- } \\
\text { Naisaburi } \\
\end{array}$ & $\begin{array}{l}\text { Kisah Wudhu Nabi saat } \\
\text { Fathul Makah dengan } \\
\text { mengusap sepatu Beliau }\end{array}$ & Shahih \\
\hline 23 & $\begin{array}{l}\text { Musnad al- } \\
\text { Tayalusi }\end{array}$ & $\begin{array}{l}\text { Abu Daud bin } \\
\text { Sulaman bin } \\
\text { Daud bin } \\
\text { Jarwadi al- } \\
\text { Thayalusi } \\
\end{array}$ & $\begin{array}{l}\text { Menghormati Keluarga } \\
\text { Nabi }\end{array}$ & Shahih \\
\hline 24 & $\begin{array}{l}\text { Sunan Abi } \\
\text { Muslim al- } \\
\text { Kaji }\end{array}$ & $\begin{array}{l}\text { Abu Muslim } \\
\text { al-Hafiz al- } \\
\text { Kaji }\end{array}$ & $\begin{array}{l}\text { Anjuran menghidupkan } \\
\text { tanah yang mati dan } \\
\text { menanam pohon atau } \\
\text { tumbuh-tumbuhan }\end{array}$ & Shahih \\
\hline 25 & $\begin{array}{l}\text { Musnad } \\
\text { Abi Na'im } \\
\text { Ibn Adi al- } \\
\text { Jurjani }\end{array}$ & $\begin{array}{l}\text { Abu Na'im } \\
\text { Abdul Malik } \\
\text { bin } \\
\text { Muhammad } \\
\text { bin Adi al- } \\
\text { faqiih al- } \\
\text { Jurjani }\end{array}$ & $\begin{array}{l}\text { Bilal diperintahkan Azan } \\
\text { lalu disusul dengan Iqomat }\end{array}$ & Shahih \\
\hline 26 & $\begin{array}{l}\text { Musnad } \\
\text { Abd bin } \\
\text { Hamid }\end{array}$ & $\begin{array}{l}\text { Abd bin } \\
\text { Muhammad }\end{array}$ & $\begin{array}{l}\text { Waspada terhadap orang- } \\
\text { orang munafik yang suka } \\
\text { menipu dengan kata-kata } \\
\text { hikmahnya }\end{array}$ & La Ba’s \\
\hline 27 & $\begin{array}{l}\text { Musnad al- } \\
\text { Kubra al- } \\
\text { Bujari }\end{array}$ & $\begin{array}{l}\text { Abu Bakar al- } \\
\text { Hafiz Ahmad } \\
\text { bin Umar bin }\end{array}$ & $\begin{array}{l}\text { Menceritakan keingkaran } \\
\text { orang-orang Jahiliyah }\end{array}$ & Ghairu Ma'ruf \\
\hline
\end{tabular}




\begin{tabular}{|c|c|c|c|c|}
\hline & & $\begin{array}{l}\text { Abdul Khalaf } \\
\text { al-Bazari }\end{array}$ & & \\
\hline 28 & $\begin{array}{l}\text { Musnad al- } \\
\text { Hamidi }\end{array}$ & $\begin{array}{l}\text { Al-Imam al- } \\
\text { Hafiz Abu } \\
\text { Bakar } \\
\text { Abdullah bin } \\
\text { Zubair al- } \\
\text { Quraisy abu } \\
\text { Hazim al- } \\
\text { Maki }\end{array}$ & $\begin{array}{l}\text { Misi Nabi diutus oleh } \\
\text { Allah }\end{array}$ & Shahih \\
\hline 29 & $\begin{array}{l}\text { Musnad } \\
\text { Ishaq }\end{array}$ & $\begin{array}{l}\text { Ishaq bin } \\
\text { Rahawiyah }\end{array}$ & $\begin{array}{l}\text { Larangan memecahkan } \\
\text { dirham yang telah } \\
\text { bebentuk mata uang }\end{array}$ & Shahih \\
\hline 30 & $\begin{array}{l}\text { Mushannaf } \\
\text { Abd. } \\
\text { Razaq }\end{array}$ & $\begin{array}{l}\text { Abu Bakar al- } \\
\text { Hafiz Abdu } \\
\text { Razaq bin } \\
\text { Hammam bin } \\
\text { Nafi al- } \\
\text { Shan'ani al- } \\
\text { Yamani al- } \\
\text { Himyari }\end{array}$ & $\begin{array}{l}\text { Nabi Memilih Ali Bin Abi } \\
\text { Thalib sebagai Suami } \\
\text { Fatimah }\end{array}$ & Hasan \\
\hline 31 & $\begin{array}{l}\text { Musnad } \\
\text { Abi Ya’la }\end{array}$ & $\begin{array}{l}\text { Abu Ya'la al- } \\
\text { Maushili al- } \\
\text { Hafiz }\end{array}$ & $\begin{array}{l}\text { Keutamaan Menghapal } \\
\text { atau menjaga dan } \\
\text { mengamalkan } 40 \text { hadis } \\
\text { Nabi SAW }\end{array}$ & Hasan \\
\hline 32 & $\begin{array}{l}\text { Abi Bakar } \\
\text { bin Abi } \\
\text { Syaibah }\end{array}$ & $\begin{array}{l}\text { Abu Bakar bin } \\
\text { Abi Syaibah }\end{array}$ & $\begin{array}{l}\text { Bahasa Nabi Ismail yang } \\
\text { diajarkan Jibril kepada } \\
\text { Nabi Muhammad SAW }\end{array}$ & Hasan \\
\hline 33 & $\begin{array}{l}\text { Musnad } \\
\text { Abi } \\
\text { Zakaria al- } \\
\text { Himmani }\end{array}$ & $\begin{array}{l}\text { Yahya bin } \\
\text { Abdul Hamid } \\
\text { Abu Zakaria } \\
\text { al-Himmani } \\
\text { al-Kufi }\end{array}$ & $\begin{array}{l}\text { Larangan berdusta atas } \\
\text { nama Nabi }\end{array}$ & Shahih \\
\hline 34 & $\begin{array}{l}\text { Musnad } \\
\text { Al- } \\
\text { Bughawi }\end{array}$ & $\begin{array}{l}\text { Al-Hafiz } \\
\text { Abdullah bin } \\
\text { Muhammad } \\
\text { bin Abdul } \\
\text { Aziz al- } \\
\text { Marzabani al- } \\
\text { Bugawi } \\
\end{array}$ & $\begin{array}{l}\text { Mengisahkan seorang laki- } \\
\text { laki yang berdusta atas } \\
\text { nama Nabi, lalu Nabi } \\
\text { menyuruh untuk } \\
\text { membunuhnya dan } \\
\text { ancaman neraka bagi yang } \\
\text { berdusta atas nama Nabi }\end{array}$ & Shahih \\
\hline 35 & $\begin{array}{l}\text { Musnad } \\
\text { Hannad }\end{array}$ & $\begin{array}{l}\text { Abu Sirri al- } \\
\text { Hafiz Hannad } \\
\text { bin Sirri } \\
\end{array}$ & $\begin{array}{l}\text { Keutamaan Darah orang- } \\
\text { orang yang berjihad }\end{array}$ & Shahih \\
\hline 36 & $\begin{array}{l}\text { Musnad } \\
\text { Muthayyin }\end{array}$ & $\begin{array}{l}\text { Al-Hafiz Abu } \\
\text { Abdullah } \\
\text { Muhammad }\end{array}$ & $\begin{array}{l}\text { Perintah menutup Aurat } \\
\text { bagi Laki-aki }\end{array}$ & - \\
\hline
\end{tabular}




\begin{tabular}{|c|c|c|c|c|}
\hline & & $\begin{array}{l}\text { bin Abdullah } \\
\text { al-Hadrami al- } \\
\text { Mulaqab } \\
\text { Muthayyin }\end{array}$ & & \\
\hline 37 & $\begin{array}{l}\text { Musykil } \\
\text { al-Atsar }\end{array}$ & $\begin{array}{l}\text { Abu Ja'far } \\
\text { Ahmad bin } \\
\text { Muhammad } \\
\text { Salamah bin } \\
\text { Salamah al- } \\
\text { Azdi Al-Hujri } \\
\text { al-Thawahi }\end{array}$ & Memuliakan Orang tua & Hasan \\
\hline 38 & $\begin{array}{l}\text { Sunnah Al- } \\
\text { Kai }\end{array}$ & $\begin{array}{l}\text { Ibnu Manzur } \\
\text { al-Thabari al- } \\
\text { Kai }\end{array}$ & $\begin{array}{l}\text { Keutamaan Kalimat } \\
\text { Bismillah al-Rahman al- } \\
\text { Rahim }\end{array}$ & Hasan \\
\hline 39 & $\begin{array}{l}\text { Hulyatul } \\
\text { Awliya }\end{array}$ & $\begin{array}{l}\text { Abu na'im al- } \\
\text { Hafiz Ahmad } \\
\text { bin Abdullah } \\
\text { al-Asbahani }\end{array}$ & $\begin{array}{l}\text { Laknat Nabi SAW kepada } \\
\text { Mu'awiyyah (Semoga } \\
\text { Allah tidak } \\
\text { mengenyangkan perutnya } \\
\text { Muawiyah) }\end{array}$ & Shahih \\
\hline 40 & $\begin{array}{l}\text { Amalul al- } \\
\text { Yaumiah } \\
\text { al-Lailah } \\
\text { Ibn Sinn }\end{array}$ & $\begin{array}{l}\text { Ahmad bin } \\
\text { Muhammad } \\
\text { bin Ishaq Ibn } \\
\text { Sinn }\end{array}$ & $\begin{array}{l}\text { Perintah mengucapkan } \\
\text { kalimat Bismillah } \\
\text { Tawakaltu 'Alallahi Laa } \\
\text { Haula Walaa Quwwata } \\
\text { Illa Billah }\end{array}$ & Hasan Gharib \\
\hline
\end{tabular}

\section{E. Analisis Hadis}

1. Kutipan Berulang

Pada hadis yang ke 7 dan 8, al-Fadani mengutip matan hadis yang sama dari kitab dan imam hadis yang sama pula yaitu kitab al-Muwatha karya Imam Malik namun riwayat yang berbeda. Meskipun matan dan sumber yang sama, namun riwayat berbeda dan kualitas pun berbeda. Hadis ke 7 riwayat Yahya bin Yahya al-Laitsi dengan sanad Shahih dan hadis ke 8 riwayat Muhammad bin Hasan dengan sanad Aziz. itulah alasan mengapa al-Fadani mengutip seperti itu.

\section{Hadis Bukit Aqiq}

Selain menampilkan pesan hadis, al-Fadani juga memberikan syarah pada hadis-hadis tertentu saja yang dianggap perlu untuk dijelaskan maksud hadis tersebut. Syarah tersebut terkadang dijelaskan secara singkat saja, terkadang juga sangat panjang. Untuk yang singkat misalnya beliau saat menjelaskan Bukit Aqiq pada hadis pertama yang diambil dari shahih Bukhari. Beliau menjelaskan Huwa wadi bi qorib al-baqi, bainahu wa 
baina madinah arba'ata amyal (Bukit dekat baqi'. Jarak antara bukit tersebut dengan Madinah 4 mil). ${ }^{21}$

\section{Hadis laknat Kepada Muawiyah}

Adapun keterangan beliau yang cukup panjang saat mensyarah hadis yang ke-39. Pada hadis tersebut berisi tentang laknat atau kutukan Nabi kepada Muawiyah bin Abi Sufyan yang disuruh beberapa kali menghadap Nabi tetapi pada saat disuruh menghadap tersebut Mu'awiyah sementara makan, maka Nabi mengucapkan kalimat semoga Allah tidak mengenyangkan perutnya. menurut al-Fadani hadis ini harus dijelaskan maksudnya, agar tidak terjadi kesalah pahaman ditengah umat bahwa Rasulullah melaknat Muawiyah, sebagaimana yang terjadi pada golongan Syi' ah yang menjadikan hadis ini untuk mencela Muawiyah.

Al-Fadani dalam mensyarah hadis tersebut mengutip sebuah hadis "barang siapa yang dilaknat dan dicaci maki oleh Nabi Muhammad atau mengutuknya maka ia berhak memperoleh zakat, pahala dan rahmat dari Rasulullah". Dalam hadis yang diriwayatkan oleh Abu Hurairah, Rasulullah pernah bersabda, "Ya Allah, sesungguhnya aku hanyalah manusia, siapa saja dari umat Islam yang pernah saya caci maki, pernah saya laknat, pernah saya cambuk, maka aku akan berikan zakat dan rahmat kepadanya". Adapun beberapa hadis lain tentang perkara ini pernah diriwayatkan oleh 'Aisyah, Jabin bin Abdullah, dan Anas. ${ }^{22}$

Selain itu, al-Fadani mengutip pendapat Imam Nawawi dalam menerangkan hadis tersebut dalam buku Syarahnya: "Jika ada yang berkata,' bagaimana bisa Rasulullah mengutuk orang yang tidak pantas dikutuk, mencaci, melaknat dan lain sebagainya? Dalam hal ini, ada dua pendapat ulama. Pertama, pada hakekatnya kutukan tersebut tidak dianggap oleh Allah SWT karena pada kenyataannya kutukan tersebut merupakan bentuk penghargaan. Oleh karena itu, Rasulullah SAW memberikan hak kepada orang yang pernah beliau kutuk berdasarkan syariat yang disampaikannya. Sebenarnya, Rasulullah tidak menginginkan hal itu tetapi beliau diperintahkan untuk memutuskan sesuai yang zahir (nampak) dan hal yang rahasia (tidak nampak) menjadi keputusan Allah SWT.

Kedua, Panggilan nama, laknat, dan caci maki yang penah dilontarkan oleh Rasulullah sebenarnya bukan keinginannya. Tetapi hal itu

\footnotetext{
${ }^{21}$ Al-Fadani, Arba'atun haditsan, h. 6

${ }^{22}$ Ibid., h. 81
} 
sudah menjadi tradisi yang berlaku di bangsa Arab yang berkata tanpa ada niat menyakiti, seperti perkataan, "di bagian tanganmu ada tanda mandul dan serak sepertiku". Seperti dalam hadis dikatakan, "Semoga kamu cepat tua" atau dalam hadis yang diriwayatkan oleh Mu'awiyyah,diri saya sendiri dan orang lain. Sesungguhnya Dialah sebaik-baik tempat memohon.Demikianlah hakekat panggilan yang kadang membuat Rasulullah SAW takut bila hal itu bisa menciptakan satu masalah. Oleh karena itu, belia berdoa kepada Allah agar panggilan, umpatan, dan hinaan dapat diganti dengan rahmat, penghapus dosa, pembersih, dan pahala.Hal seperti ini jarang dan sangat langka terjadi ada diri Rasulullah SAW. Beliau tidak pernah berbuat keji, melaknat dan balas dendam terhadap dirinya sendiri. ${ }^{23}$

\section{Netralitas Al-Fadani}

Jika diperhatikan materi-materi hadis di atas, tampak al-Fadani menarik ke wilayah perdebatan aliran kalam Sunni-Syiah. Hadis ke 23 tentang menghormati keluarga Nabi dan hadis ke 30 tentang kisah Nabi memilih Ali bin Abi Thalib sebagai suami Fatimah merupakan hadis-hadis yang sering dianggap sebagai hadis Syi'ah. Namun al-Fadani juga memberikan penjelasan yang cukup panjang ketika mensyarah hadis ke 39 tentang laknat Nabi Muhammad SAW kepada Mu'awiyah. Menurut alFadani hadis ini sering digunakan oleh orang Syi'ah untuk mencela Mu'awiyah. Namun al-Fadani menjelaskan dengan mengutip pendapat alNawawi bahwa itu bukanlah laknat Nabi sebagaimana telah dijelaskan di atas. Di sini nampak netralitas al-Fadani dalam menyelesaikan perdebatan panjang antara Sunni-Syi'ah.

Manfaat secara praksis jika dilihat dari materi-materi hadis dalam kitab ini sebagaimana dijelaskan di atas adalah untuk menjawab konteks sosial yang meliputi al-Fadani pada saat itu. Secara garis besar hadis-hadis dalam kitab ini meliputi masalah aqidah atau keimanan, ibadah, hukum, sosial, akhlak, kebersihan/penampilan, dan jihad. Tema-tema ini adalah sesuatu yang banyak diperbincangkan para ulama pada saat itu. Hal ini terbukti jika kita melihat materi-materi pembahasan dalam kitab-kitab mereka. Oleh sebab itu, al-Fadani ingin memosisikan diri dalam perbincangan itu dengan memberikan kontribusi pemikiran atau ijtihad sebagaimana yang nampak dalam kitab beliau ini.

${ }^{23}$ Ibid., h. $81-82$ 
Setiap mengakhiri syarah hadis tersebut baik yang singkat atau yang panjang diakhiri dengan huruf I اله م y yang berarti singkatan dari أعلم (hanya Allah yang lebih mengetahui), sebagai bentuk ketawadhuan beliau di hadapan manusia terutama di hadapan Allah SWT.

\section{F. Kualitas Kitab Rujukan}

Dari empat puluh kitab tersebut, sembilan diantaranya adalah kitab yang sangat kita kenal ke-mu'tabar-annya. Kitab-kitab tersebut biasanya lebih dikenal dengan sebutan kutubut tis'ah. Berikut penjelasan singkat kesembilan kitab induk hadis tersebut: ${ }^{24}$

Pertama, Sahih al-Bukhari ditulis oleh Imam Bukhari. Beliau adalah seorang ahli hadis yang mendapatkan gelar tertinggi, yang disepakati para ulama sebagai pengarang kitab yang tersahih yaitu setelah al-Qur'an.Kedua, Kitab Sahih Muslim. Kitab ini oleh para ulama hadis dan dikategorikan sebagai salah satu kitab rujukan standar dari banyaknya koleksi kitab hadis. Ketiga, Kitab Al-Muwatta' Imam Malik. Sebagian ulama' berpendapat bahwa al-muwatta'lebih sahih dari Sunan ibn Majjah atau bahkan menempati peringkat pertama dalam hal kesahihan setelah Sahih al-Bukhari dan Sahih Muslim.Keempat, Kitab Musnad Ahmad ibn Hanbal. Hadis-hadis dalam musnad Ahmad semuanya bisa dijadikan Hujjah dan merupakan kitab termasyhur dan terbesar pada periode kelima perkembangan hadis.

Kelima kitab Sunan ad-Darimi menempati posisi yang tinggi dikalangan ulama ahli hadis.Keenam Kitab Sunan Al-Tirmizi. Imam Tirmidzi tergolong kelompok orang-orang yang dapat dipercayai dan kukuh hafalannya dan semua hadits yang terdapat dalam kitab ini bisa diamalkan. Ketujuh, Kitab Sunan Abu Daud sebuah kitab yang belum pernah disusun oleh kitab yang lain yang menerangkan hadis-hadis hukum sepertinya. Beliau menjadi hakim antara ulama dan para fuqaha' yang berlainan mazhab. Kedelapan, Kitab Sunan Nasa'i adalah kitab yang derajatnya lebih tinggi dari sunan Abu Dawud, sunan At Turmudzi, bahkan ada yang mengatakan rijalul hadits yang dipakai lebih tinggi nilainya daripada yang dipakai Imam Muslim. Kesembilan, kitab Sunan Ibnu Majah merupakan kitab yang memiliki keunggulan dalam cara pengemasannya serta memuat hadis-hadis yang tidak ditemukan dalam kutub al-Kamsah.

${ }^{24}$ Fatchur Rahman, Ikhtisar Mushthalahul Hadis (Bandung: PT. Alma'arif, 2001), h. 3233 
Selain itu, al-Fadani juga menggunakan pendapat para ulama sebelumnya dalam beberapa hal seperti dalam mensyarah hadis maupun menilai kualitas hadis. Dalam mensyarah hadis ulama dan kitab-kitabnya yang menjadi rujukan antara lain Ibnu Hajar al-Atsqalani dalam Fathul Bari, Ibn Shalah, Imam an-Nawawi dalam al-Tahjib, Abu Ya'la dalam Ahkam al-Suthaniyah dan Ibn Katsir melalui al-Bidayah wa an-Nihayah. Namun lebih banyak hadis yang beliau syarah dengan pendapatnya sendiri dan kadang beliau tidak memberikan syarah apapun. Jadi, intinya dalam memberikan syarah hadis lebih banyak dengan metode bil ra'yi (pendapat al-Fadani sendiri) dan sebagian kecilnya dengan bil ma'tsur (pendapat ulama terdahulu).

Untuk hadis-hadis yang disyarah dengan pendapat beliau sendiri berkaitan dengan hadis-hadis tentang masalah sosial, penjelasan suatu tempat dimana beliau pernah melihat langsung tempat itu (misalnya dalam syarah hadis pertama), dan persaudaraan sesama muslim. Adapun hadis yang disyarah dengan metode bil ma'tsur adalah hadis-hadis yang berkaitan dengan akidah, ibadah ritual dan masalah-masalah hukum/fiqh.

Dalam menilai kualitas hadis mengutip pendapat Imam hadis meskipun beliau lebih banyak menilai kualitas hadis sendiri dan melakukan takhrij pada riwayat Imam hadis yang lain.

\section{G. Kualitas Pengetahuan Al-Fadani}

Sanad atau isnad ${ }^{25}$ dalam literatur Ilmu Hadis menempati posisi yang sangat urgen dan mendasar. Sehingga tidak heran kalau ulama besar sekaliber Abdullah Ibn al-Mubarak (w. $181 \mathrm{H}$ ) menyatakan bahwa sanad termasuk bagian dari agama Islam sendiri, seandainya tidak ada sanad, niscaya setiap orang akan bebas mengatakan apa yang dia kehendaki. ${ }^{26}$ senada juga diungkapkan oleh Imam al-Tsauri (w. $159 \mathrm{H}$ ), beliau menegaskan bahwa sanad adalah senjata orang-orang yang beriman. ${ }^{27}$ Imam Suyuthi (w. $911 \mathrm{H}$ ) dalam Tadrib-nya pernah menukil perkataan Muhammad bin Aslam al-Thûsi (w. 242 H) yang menyatakan bahwa

\footnotetext{
${ }^{25}$ Usman Sya'roni, Otentisitas Hadis Menurut Ahli Hadis dan Kaum Sufi, (Jakarta: Pustaka Firdaus, Cet. II, 2008), h. 9

${ }^{26}$ Muhyiddin Abu Zakaria bin Syaraf al-Nawawi, Syarah Shahih Muslim li al-Nawawi, (Cet. IV., Mesir: Darul Hadis, 2001), h. 120

27 Jalal al-dien Al-Qasimi, Qawaid al-Tahdis min Funun Mushthalah al-Hadis, (Cet.I, Beirut: Dar al-Nafais, 1987), h. 210
} 
dengan dekatnya sanad (kepada sumbernya) akan membawa dekatnya (seseorang) kepada Allah SWT. ${ }^{28}$

Pemahaman ini menjadi pijakan al-Fadani dalam membentuk dirinya menjadi ahli hadis dalam bidang sanad. Kepakaran beliau dalam bidang sanad membuatnya digelari sebagai musnid dunya (pemilik sanad terbanyak di dunia). Kelayakan Sheikh Yasin al-Fadani sebagai seorang muhadits kontemporar didasari atas kriteria muhaddits menurut Abu alLayth al-Khayr Abadi, ia menulis sebagaimana berikut: ${ }^{29}$

"(Ahli Hadith) adalah orang yang banyak menyibukkan diri dan ikhlas dengan Hadith dan ilmunya, membaca, mempelajari, mengkaji dan mempunyai pengetahuan terhadap Hadith-hadith dan jalur-jalur serta mengetahui (keadaan) para perawinya dari aspek jarh dan ta"dil, mengetahui pula karya-karya mengenai Hadith dan para perawinya, karya-karya syarah Hadith, dan mempunyai basirah (kearifan) dengan muamalah (interaksi) bersama hadith-hadith, terang (baginya) keadaan Hadith-hadith itu, sebab wurudnya hadith (asbab al-wurud), ilal (kecacatannya), lebih lagi tentang mukhlatif al-hadith dan mushkil al-hadith".

Mencermati hal ini maka dapat dikatakan bahwa Sheikh Yasin alFadani telah memenuhi kriteria yang disebutkan. Beliau tidak saja mempunyai pengetahuan terhadap kitab-kitab yang dimaksud yang dapat dibuktikan melalui karya-karyanya, tetapi juga telah banyak mengkhidmatkan dirinya dalam mengkaji dan menulis hadis-haids Nabi SAW menelurusi sanad-sanadnya dan meriwayatkannya secara musnad sehingga kepada Rasulullah SAW melalui para perawi hadis yang telah meriwayatkan Hadis-hadis di dalam kitab-kitab mereka, seperti al-Kutub al-Tis'ah, dan kitab-kitab lainnya seperti kitab-kitab Sunan, Masanid, Musannaf, Ma'ajim, Sihah dan selainnya. Maka itu pemahaman Syekh Yasin al-Fadani di bidang hadis dan kepakaran beliau dapat dikenali dari

\footnotetext{
${ }^{28}$ Jalal al-Dien Al-Suyuthi, Tadrib al-Rawi syarh Taqrib al-Nawawi, (Cet.I, Mesir: Darul Hadis, 2004), h. 431

${ }^{29}$ Muhammad Abu al-Layth Abadi , 'Ulum al-Hadith Asiluhawa Ma'asiruha (Cet. ke-6, Bangi: Dar al-Shakir, 2009), h. 30
} 
terhadap istilah-istilah yang diguna pakai dalam tradisi pengajian hadis sama ada riwayah al-Hadith mahupun dirayah al-Hadith. ${ }^{30}$

\section{H. Kesimpulan}

Syekh Muhammad Yasin al-Fadani adalah ulama hadis yang layak mendapatkan gelar musnid al-dunya (pemilik sanad terbanyak di dunia). Kelayakan ini memiliki alasan bahwa al-Fadani mampu menguraikan sanad hadis dari Nabi sampai kepada beliau. Kemampuan itu pula lahir karena al-Fadani dikenal sebagai orang yang suka memburu sanad, silsilah periwayatan hadits dan ijazah ilmu atau kitab. Keberhasilan al-Fadani dalam menelusuri sanad sampai kepada Nabi, sesungguhnya membuka pintu yang selebar-lebarnya bagi siapapun yang ingin mengembangkan dan melanjutkan tradisi khas keilmuan Islam yang diakui oleh dunia intelektual Barat, yaitu ketersambungan sanad keilmuan. Hal ini dapat dilakukan oleh generasi saat ini dengan cara menelusuri hadishadis yang beliau riwayatkan kepada murid-muridnya. Dari muridmuridnya itulah kita bisa belajar hadis terutama sanadnya.

Tulisan ini diharapkan menjadi inspirasi bagi siapapun yang ingin meneliti kitab-kitab hadis, khusunya kitab hadis Nusantara yang ditulis oleh al-Fadani. Dengan demikian kita bisa mendapatkan pemikiran, motifasi dan gagasan secara berbeda yang ada dalam karya-karya alFadani lainnya. Hal ini mesti dilakukan sebab al-Fadani adalah ulama besar yang telah mewariskan ratusan karya dalam berbagai bidang keilmuan Islam khususnya tentang hadis. Warisan ini tentu menjadi warisan berharga bagi generasi masa kini dan generasi akan datang, khusunya generasi muslim Indonesia. Al-Fadani mengajarkan kepada kita pentingnya menjaga hadis-hadis Nabi dengan cara mempelajarinya baik dari segi matan maupun sanadnya. Keteladanan beliau tersebut dicontohkan dengan ketekunannya dalam menguasai sanad hadis Nabi.

\footnotetext{
${ }^{30}$ Rudi Edwaldo Jasmit, Sumbangan Syeikh Yasin Al-Fadani Dalam Karya Al-Arba'inat: Analisis Terhadap Kitab Al-Arba'in Al-Buldaniyah, Disertasi, (Kuala Lumpur: Universitas Malaya, 2015), h. 7-71
} 


\section{DAFTAR PUSTAKA}

Abadi, Muhammad Abu al-Layth, 2009, 'Ulum al-Hadith Asiluhawa Ma'asiruha, cet. ke-6, Bangi: Dar al-Shakir.

Al Naisaburiy, Abu Abdillah al Hakim, 1918, Al Mustadrak Al Shahihaini, Juz I, Beirut : Dar Al Fikr.

Al-Fadani al-Maki, Abi Al-Faidh Muhammad bin Yasin, 1407 H/1987 M, Arbauna Haditsan min Arbaina Kitaban an Arba'ina Syaikhan, Beirut: Dar al-Basyair al-Islamiyah.

al-Nawawi, Muhyiddin Abu Zakaria bin Syaraf, 2001, Syarah Shahih Muslim li al-Nawawi, Mesir: Darul Hadis, Cet. IV.

Al-Qasimi, Jalal al-dien, 1987, Qawaid al-Tahdis min Funun Mushthalah al-Hadis, Cet.I., Beirut: Dar al-Nafais.

Al-Suyuthi, Jalal al-Dien, 2004, Tadrib al-Rawi syarh Taqrib al-Nawawi, Cet., Mesir: Darul Hadis.

Ash shiddiqiy, M. Hasbi, 2001, Sejarah Pengantar Ilmu Hadis, Cet.VIII;Semarang: Pustakarizki putra.

Ash shiddiqiy, M. Hasbi, t.th., pokok-pokok ilmu dirayah hadis, Jilid II;Cet,VIII; Jakarta :Bulan Bintang.

Azra Azyumardi, 2013, JaringanUlama Timur Tengah dan Kepulauan Nusantara Abad XVII \& XVIII; Akar Pembaruan Islam di Indonesia Jakarta: Kencana.

Husna Jannatul, 2012, Syeikh Yasin Padang dan Ilmu Tafsir: Sorotan Terhadap Fayd al-Khabir, Proceedings: The 2and Annual International Qur'anic Conference, Malaya Unversity.

Ismail, M. Shudi, 2003, Cara Prakti Mencari Hadis, Cet,I;Yogyakarta :Teras.

Jasmit, Rudi Edwaldo, 2015, "Sumbangan Syeikh Yasin Al-Fadani Dalam Karya Al-Arba'inat: Analisis Terhadap Kitab Al-Arba'in AlBuldaniyah", Disertasi, Universitas Malaya, Kuala Lumpur. 
Mahdi, Abu Muhammad Abduh, 1994, Metode Tahkrijul Hadis, terj. Said Agil Husin Munawar dkk. Cet. I, Semarang: Dina Utama Semarang.

Rahman, Fatchur, 2001, Ikhtisar Mushthalahul Hadis, Bandung: PT. Alma'arif.

Suprapto M. Bibit, 2009, Ensiklopedi Ulama Nusantara Jakarta: Gelegar Media Indonesia.

Sya'roni Usman, 2008, Otentisitas Hadis Menurut Ahli Hadis dan Kaum Sufi, Cet. II., Jakarta: Pustaka Firdaus.

Syafi al-Damsyiqi Abi Zakaria Muhyi al-Din bin Syarif al-Yadain alNawawi , t.th., al-Arba'ina Fi Mabani al-Islami wa Qawa'id alAhkam, ttp: tp. 